the sixteenth century before Christ, a period at which the Minoan culture was at its zenith. The discovery is otherwise remarkable in that it includes swords of exceptionally large size, which are said to be greater in number than any other single find of swords ever made in prehistoric Europe. Associated with them were some hundreds of copper axes, a number of silver axes and twenty-seven gold double axes with golden shafts. The claim that the newly discovered script is itself unknown, but bears a resemblance to characters known from the Phaistos inscription, constitutes the chief interest of the find; though it has other points which will intrigue archæologists. In the circumstances, its full publication should be delayed as little as possible, even though this should entail postponement of full discussion.

\section{Soviet Stratosphere Research}

IT is learnt from the reports in The Times of June 27 and 28 that stratosphere research is very active in the U.S.S.R. It will be recalled that the Russians hold the altitude record of 12 miles for manned balloons made by M. Prokofiev in October 1933, whilst the U.S.S.R. Stratostat, which crashed in January 1934, killing its occupants, rose even higher. The present ascent, which was only of $2 \frac{1}{2}$ hours' duration, was made from Moscow on June 26, during which time the balloon travelled 100 miles due south. The commander-pilot was M. Kristap Zille, who was accompanied by a physicist, Prof. Alexandre Verigo, of the Central Geophysical Observatory at Leningrad, and a mechanic named Prilutsky. It is stated that during the short flight the altitude reached was more than 9 miles and that the crew landed safely by parachute, apparently as an exercise. Prokofiev's gondola was used, its instruments were landed intact, photographs of the earth were made and varied cosmic ray records taken. It is incidentally stated, though extremely interesting to hear, that the commander had made two other stratosphere ascents in June.

\section{London Transport Scheme}

Arrangements have been concluded between the Government and the Standing Joint Committee of the London Passenger Transport Board and the main line railways for the development of a transport seheme for London. On June 5, the Chancellor of the Exchequer announced to the House of Commons that a $£ 35,000,000$ plan had been concluded. In addition to the extensive schemes included in the Private Bill of the Transport Board, it is intended to electrify the suburban lines of the L. and N. E. Railway in north-east London entering Liverpool Street, and to extend tube railways to give new connexions between these electrified lines and the City and the West End. The high level at which Government credit now stands enables an Exchequer guarantee to be given of loans sufficient to enable the whole undertaking to be started at once. It involves the building of about 12 miles of new tube railways, the electrification of 44 miles of suburban railway and the doubling and electrification of about 12 miles of further suburban railways. In addition, we were glad to learn that trolley buses are to be substituted for tram cars on 148 route miles. These buses, like the cars, are driven by electricity, but they leave the highways more open and much safer for road traffic. It is hoped to complete the works within five years from the date of the loan. Among the improvements, we notice that escalators will be used instead of lifts and will provide ample accommodation for the increased traffic.

\section{Gas or Electricity for Domestic Heating?}

THE question of whether to heat our houses by gas or electricity is discussed in an article in the Nineteenth Century and After of June by Prof. W. A. Bone. He is naturally proud of the progress made by the gas industry during the past hundred years. $\mathrm{He}$ points out that the electrical industry is only fifty years old and has the attractiveness and selfconfidence of youth, and so is apt to impress uncritical minds with its superiority. We agree that a London gas consumer buys as much potential heat for $8 \cdot 6 d$. as would cost an electricity consumer nearly half a crown at $I d$. per unit. On the other hand, every bit of the electric heat can be utilised, whilst an appreciable fraction of the gas heat passes up the chimney. Electricians are well aware of the relative costs of gas and electricity for heating, and where economy is the primary consideration, water heating by electricity is only advisable in certain cases. We do not agree with Prof. Bone that a chimney is necessary for the suitable ventilation of bed- and living-rooms. Many systems for ventilating rooms have been devised. Possibly in a few years time chimneys will be considered relics of barbarism, and roof gardens will add to the amenity of life. In London, many consumers now get their electricity at $0 \cdot 5 d$. per unit and are delighted with their electric heaters and cookers, even although they have previously had extensive experience of gas rings and fires. Electricians are continually experimenting, just as are gas engineers; and are remedying some of the defects of the early installations. It is now customary to have the switch for the electric fire about three feet above the floor so that the heat can be regulated without moving an armchair.

\section{Institute of Physics Lectures at Manchester}

THE annual lectures on recent advances in physics arranged by the Manchester and District Local Section of the Institute of Physics were held in the Physics Department of the University of Manchester on June 24 and 26. The first lecture was given by Prof. Franz Simon, who is now working at the Clarendon Laboratory, Oxford, and whose researches on low temperatures are well known. He chose as his subject "Low Temperature Research-its Objects and Methods", and gave an account of recent advances in experimental technique whereby temperatures of the order of a fraction of a degree from absolute zero may be obtained. The principles underlying the experimental methods were considered 
and reference made to the peculiar properties of certain substances at low temperatures. Prof. M. Polanyi, professor of physical chemistry in the University of Manchester, gave the second lecture, his subject being "Reaction Velocity and Thermodynamics". He discussed the general effect of pressure on the velocity of chemical reactions, using relations deduced in accordance with thermodynamical principles, and referred among other things to the alteration of the equilibrium of reactions due to pressure, the grouping of reactions, and the connexion between reaction velocity and the heat of reaction. $\mathrm{He}$ also described recent work on the mechanism of ionogenic reactions. The lectures were well supported by members and friends, and were followed by helpful discussions of the various points raised.

\section{Chemical Industry and Water Problems}

THE presidential address of Mr. Edwin Thompson, at the annual general meeting of the Society of Chemical Industry at Glasgow on July 2, dealt with the question of water supply in Great Britain and covered a wide range of topics in that connexion. Mr. Thompson considered the problem of a national water policy to call for immediate investigation. $\mathrm{He}$ deplored the spirit of localism which still manifests itself in connexion with every water supply scheme of magnitude, despite the recommendation made nearly seventy years ago by the Royal Commission of 1868 "that no town should be allowed to appropriate a source of supply which naturally and geographically belongs to a town or district nearer to such source, unless under special eircumstances which justify the appropriation". He said there is too much selfishness among water undertakings, and that they could do much to relieve the needs of those who have no water supply. He went on to discuss a number of difficulties and problems which are associated with questions of supply : water pollution, rural requirements, misuse and waste of water, the increase during recent years of the per capita consumption, diversion of supplies for canals, storage reservoirs, biological factors of storage, sewage effluents into rivers, compensation water, etc. He alluded to and endorsed the necessity for a survey of the water resources of Great Britain and instanced from the report of the British Association Committee the example set in this respect by other nations. The idea of a water grid was dismissed. The valuation of waterworks for rating purposes has a serious financial bearing on the administration and working expenses of an undertaking. The formation of a Select Committee of the Houses of Parliament to go fully into the question of national water supplies made him confident that the anxieties and hardships of the past year will never be repeated.

\section{The Annual Tables of Constants}

AT the conference of the International Union of Chemistry, held in April 1934 in Madrid, it was recommended that a substantial part of the funds at the disposal of the Union should be transferred to the International Committee of Annual Tables of
Constants, in order to assist in the publication of these valuable tables. This recommendation was passed unanimously by the Union's executive in Paris in last October and confirmed by the national organisations representing the various countries adhering to the Union, such as Verband Deutscher Chemischer Vereine representing Germany, Comité National Belge de Chimie representing Belgium, National Research Council, Division of Chemistry, representing the United States, and so on. The sum thus put at the disposal of the Committee of the Annual Tables is 150,000 franes; the amount indicates the importance which international chemical circles attach to the continuation of the Annual Tables. This sum will be used up for printing the index of the second series (vol. 6-10, 1923-1930), which is now ready. In return for this gift, the Committee of the Annual Tables is going to put at the disposal of the chemical organisations adhering to the Union a certain number of complete sets of the Tables.

\section{Atmospheric Pollution}

THE twentieth report on atmospheric pollution issued by the Department of Scientific and Industrial Research (H.M.S.O., 5s. net) records observations for the year ending March 31, 1934. This report, like its forerunners, shows that preconceived notions are not always supported by measurement. If the conditions of sampling and test are valid, then the City of London has the most polluted atmosphere observed in Great Britain, and deposits of solids and tar show annual increase. Again, foggy weather, judged by measurement of 'smoke haze', appears to reach greatest prevalence in Westminster, and some of the highest figures for sulphur pollution are also found in London observing stations. Some so-called industrial cities apparently have atmospheric conditions much superior to those in London. London may, however, take comfort from the fact that comparable measurements show that atmospheric pollution in Philadelphia is almost twice as bad. Experience is recorded with the use of a 'candle' of lead dioxide for measuring atmospheric sulphur compounds. Another interesting apparatus has been devised for recording the quantity of light. The light received by a photo-electric cell develops a current which imparts to a condenser a charge. When this reaches a certain amount, it discharges through a neon lamp and causes an ordinary counter to advance one unit. The difference between the records at the various stations is great, and it may be inferred that large improvements in atmospheric conditions are possible by using experience already known.

\section{Epidemic of Green Fly}

Wre learn from the Ministry of Agriculture and Fisheries that, in many districts in the southern half of England, oats have suffered from severe infestations by aphides or 'green fly'. Similar attacks on grassland have taken place in certain northern counties, ineluding Lancashire. The insects occurred often in swarms, smothering the crops and causing 